\title{
Giant Cumulated Condyloma (Tumor of Buschke-Lõwenstein)- A Case Report
}

\author{
Juan Francisco Rodríguez Reyes ${ }^{1}$, Jorge Agustin Satorre Rocha ${ }^{1}$, Olga Caridad Leòn Gonzalez ${ }^{1}$, José Antonio Hernández \\ Varea², and Pedro Rolando López Rodríguez ${ }^{3, *}$
}

${ }^{1}$ Assistant Professor, Department of General Surgery, Clínica Central Cira García, Cuba

${ }^{2}$ Assistant Professor, Department of Surgery, Clínica Central Cira García, Cuba

${ }^{3}$ Consultant Professor, Department of Surgery, Clínica Central Cira García, Cuba

*Corresponding author: Pedro Rolando López Rodríguez, Consultant Professor, Department of Surgery, Clínica Central Cira García, Cuba, E-mail: lopezp@infomed.sld.cu

Received: 31 Jul, 2019 | Accepted: 20 Aug, 2019 | Published: 26 Aug, 2019

Citation: Reyes JFR, Rocha JAS, Gonzalez OCL, Varea JAH, Rodríguez PRL (2019) Giant Cumulated Condyloma (Tumor of Buschke-Lõwenstein)A Case Report. J Surg Open Access 5(3): dx.doi.org/10.16966/2470-0991.188

Copyright: (C) 2019 Reyes JFR, et al. This is an open-access article distributed under the terms of the Creative Commons Attribution License, which permits unrestricted use, distribution, and reproduction in any medium, provided the original author and source are credited.

\section{Abstract}

The condylomata acuminatum or genital warts are produced by the human papillomavirus. Infection typically occurs when host, basal cells are exposed to viral infection through a damaged epithelial barrier, such as during sexual intercourse or as a product of other minor skin abrasions. In a few occasions, they can evolve with a marked growth and cause the well-known Buschke-Löwenstein syndrome or Giant condyloma acuminatum. We present a patient with Giant condylomata acuminata in the inguinal and anal regions that were surgically treated with exeresis of the inguinal lesions and electro fulguration of the annals with satisfactory evolution, without tumor recurrence at three months.

Keywords: Giant condylomata acuminata; Warty carcinoma

\section{Introduction}

Condylomata acuminata or genital warts are one of the most common sexually transmitted diseases. They are produced by the human papillomavirus. Infection typically occurs when host basal cells are exposed to viral infection through a damaged epithelial barrier, such as during sexual intercourse or as a product of other minor skin abrasions $[1,2]$.

The presence of other associated factors is necessary to produce the disease such as sexual promiscuity, poor nutrition, smoking, depression of the immune system and prolonged use of oral contraceptives [1-3].

On rare occasions, they can evolve as an invasive tumor with local malignancy, although without metastasis, equivalent to a verrucous carcinoma and it is when they are diagnosed as Buschke-Löwenstein syndrome or tumor.

\section{Case Report}

Male patient I.K.M. 47 years old, Bahamés, who attended the surgery clinic of the Central Clinic "Cira García" for presenting skin lesions in the inguinal and anal region of 5 years of evolution that have been growing progressively. It started as a "little ball" until it reached the size of a tumor lesion approximately $20 \mathrm{~cm}$ and semihard consistency. Therefore, their admission is decided to study and surgical treatment

\section{Physical examination}

Verrucous lesion of exophytic growth located in the scrotum and perineum of $10 \mathrm{~cm}$ in diameter, without the presence of suppuration or signs of ulceration (Figures 1-4) and another verrucous lesion in the right inguinal region, pedunculated approximately $20 \times 15 \mathrm{~cm}$ in diameter.

\section{Hematological and serological check was carried out}

Haemoglobin 13.5 g/l, Hto. 0.45, Leukogram $7.5 \times$ 10/L, Erythro 18, blood glucose $5.54 \mathrm{mmol}$, Cituria Negative, HIV negative, Serology, non-reactive, platelet count $321 \times 10 \mathrm{~g} / \mathrm{l}$. Thorax Rx Normal. Normal nasal and pharyngeal exudate.

\section{Rectosigmoidoscopy}

No internal injury, no anal canal involvement was observed.

He underwent complete excision of the lesion of the inguinal region and electro-fulguration of the perianal lesion. It was not necessary to perform the plastic reconstruction given the pedunculated characteristic of the inguinal lesion that was completely resected (Figures 5,6).

\section{Histological study}

Histologically there was marked hyperkeratosis and acanthosis and areas of parakeratosis with moderate spongiosis and areas of basal hyperplasia with increased melanin pigment in the basal cells with 


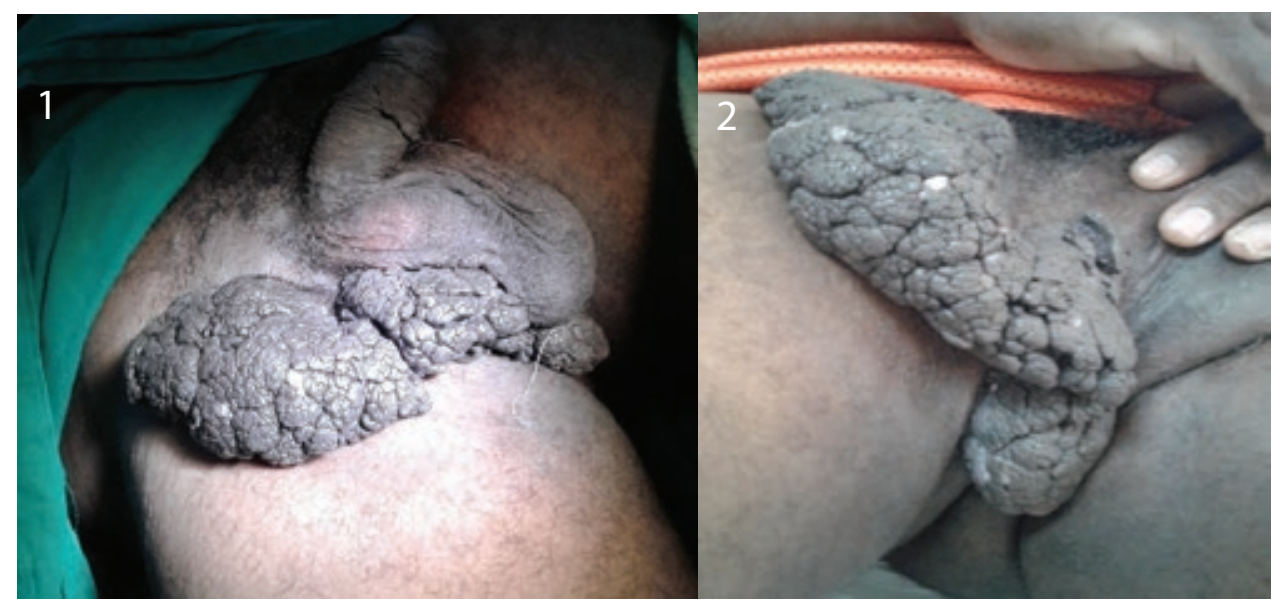

Figures 1 and 2: Condylomatous tumor lesion in the right inguinal region.

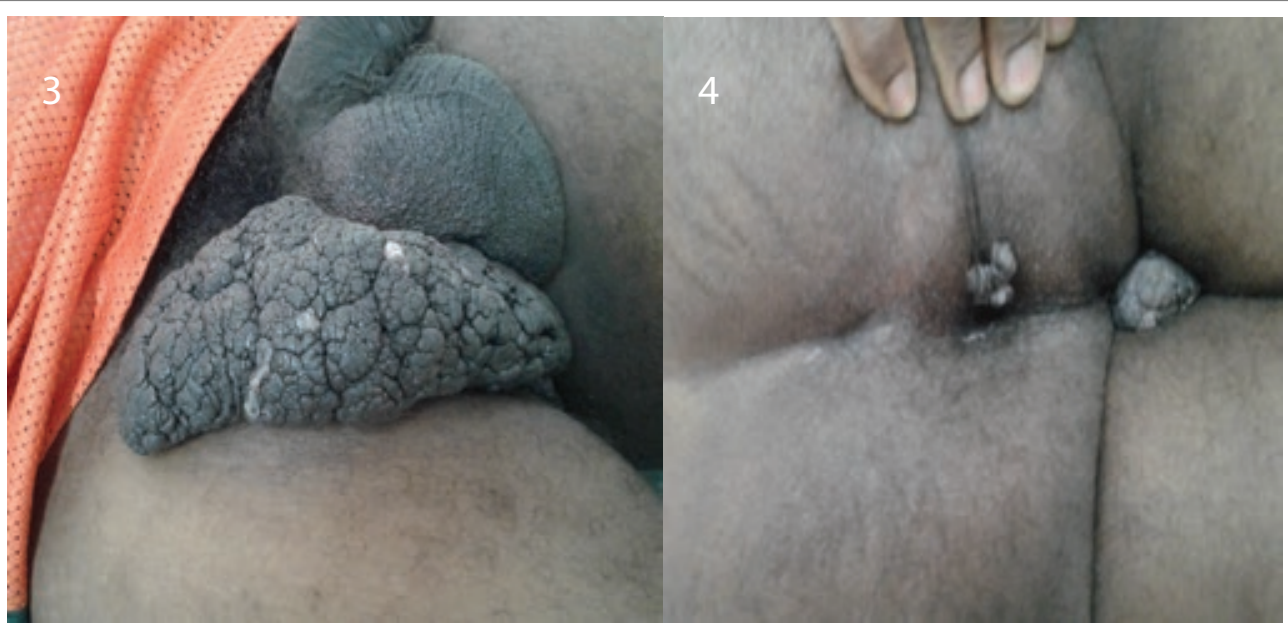

Figures 3 and 4: Condylomatous tumor lesion in the right inguinal region and anal region where the large semi-hard verrucous consistency is observed.

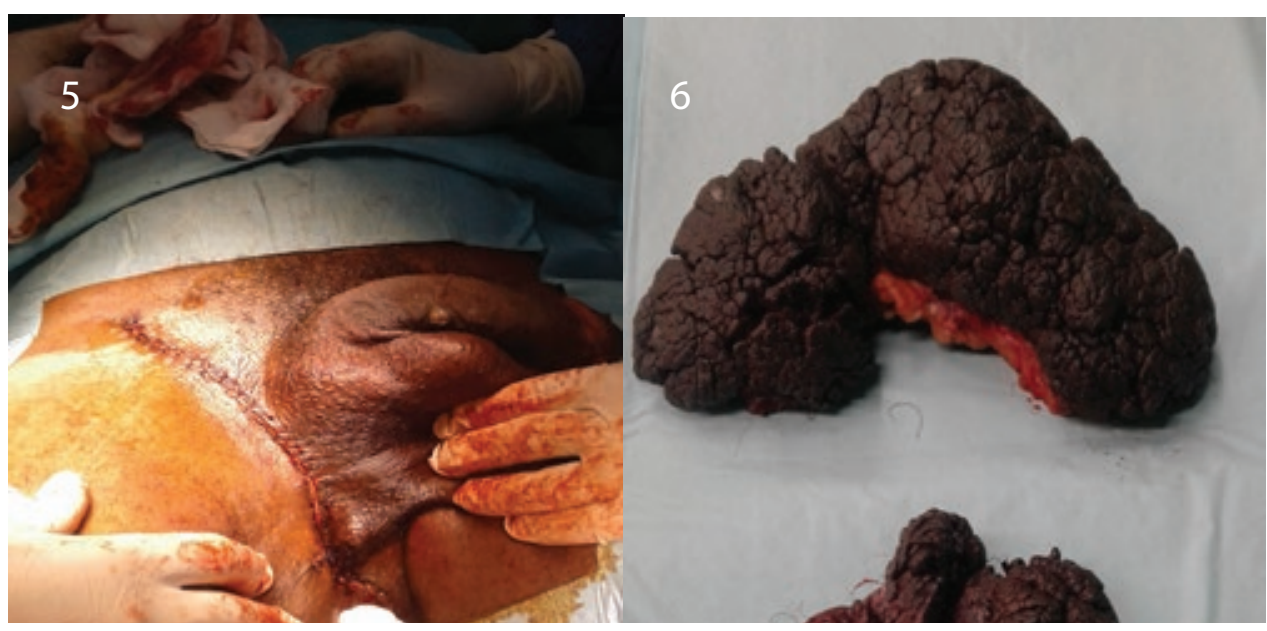

Figures 5 and 6: Condylomatous tumor lesion in the right inguinal region and anal region where the large semi-hard verrucous consistency is observed.

Citation: Reyes JFR, Rocha JAS, Gonzalez OCL, Varea JAH, Rodríguez PRL (2019) Giant Cumulated Condyloma (Tumor of BuschkeLõwenstein)- A Case Report. J Surg Open Access 5(3): dx.doi.org/10.16966/2470-0991.188 


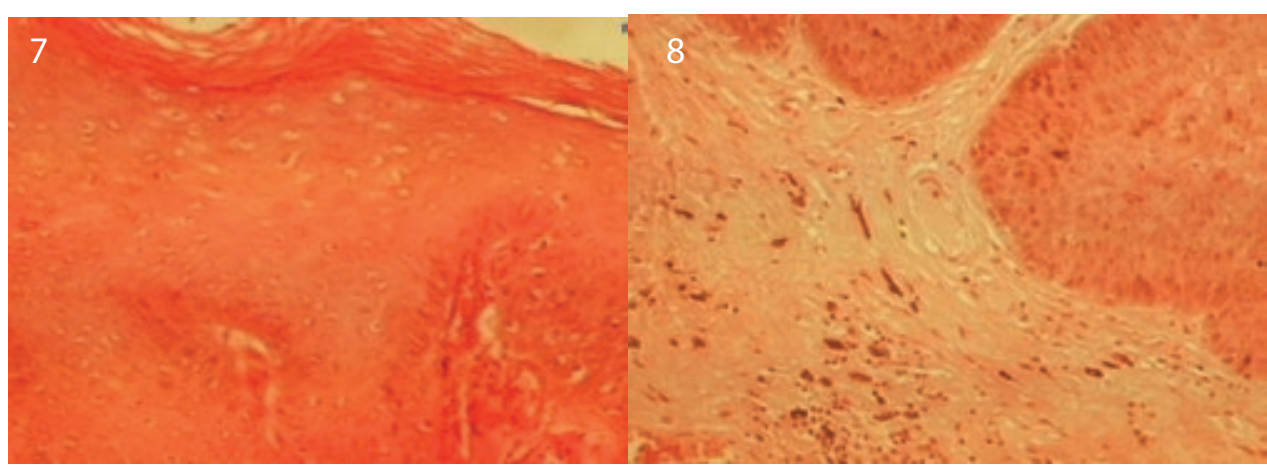

Figures 7 and 8: Hyperkeratosis with severe acanthosis with basal hyperplasia and increased melanin pigment at that level.

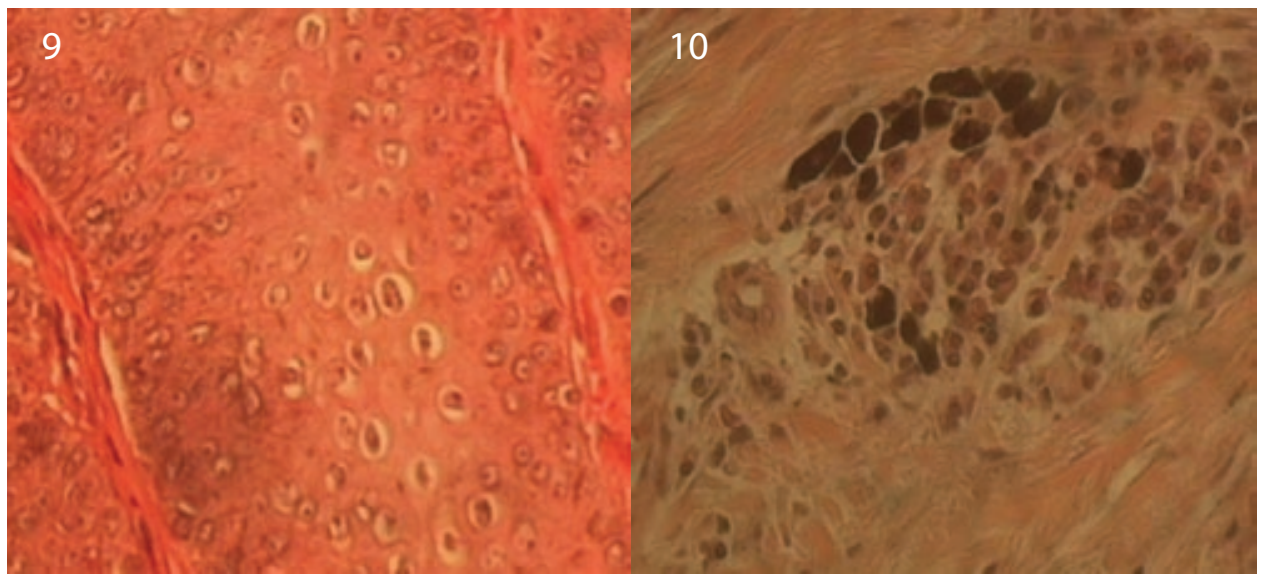

Figures 9 and 10: Presence of coilocytes in the epidermis and melanophores in the superficial dermis.

malignant cells and nucleoli prominent rosés with inclusion bodies in the epidermis (Figures 7-10). Severe papillomatosis with increased vascularization and the presence of giant cells of the foreign body type with the presence of melanophores and chronic inflammatory infiltrate in the superficial and middle dermis.

The diagnosis was concluded as a Giant condyloma acuminatum or Buschke-Lowenstein tumor.

The patient progressed satisfactorily and remains in follow-up by Surgery. There have been no recurrences after three months of surgery.

\section{Discussion}

The Buschke-Lowenstein tumor is a rare variant genital condyloma associated with infection by HPV strains 6 and 11. The average age of presentation is under 50 years, with a predominance of men in a $3: 1$ ratio. It is a pre-malignant lesion, considered anatomopathologically between condyloma acuminatum and perianal squamous cell carcinoma, which explains its high morbidity and mortality. It is characteristically bulky (more than $10 \mathrm{~cm}$ in diameter) and slowgrowing and exophytic with a tendency to invade and destroy the tissues on which it sits [4-6].

Among the risk factors that predispose to suffer from this pathology, we can find immunosuppression (mostly with HIV positive), homosexuality, promiscuity, poor genital hygiene, chronic genital infections, malnutrition, and alcoholism. Freed to its free evolution, this tumor can spread internally, fistulize, become infected, recur once it is operated (66\%) or undergoes malignant transformation (56\%) $[7,8]$.

The Buschke-Lowenstein tumor does not present cellular atypia, it is a benign tumor, but in $30 \%$ of cases it can be malignant; nevertheless, due to the great power it has of recurrence, it is considered by some authors as a malignant tumor $[9,10]$.

The differential diagnosis of Buschke-Lowenstein tumor will be made with other pathologies of genital location among them: Bowen's disease in its condylomatous form, pseudo-epitheliomatous balanitis caused by fungi, spinocellular epitheliomas, warty carcinomas, syphilis, Lymphogranuloma venereum, Durand-Nicolas-Favre disease. The difference of the Giant condyloma acuminatum is that it is more proliferating and penetrates deeper tissues than squamous cell tumors, respects the basement membrane and does not metastasize. The rest of the pathologies raised is discarded by serology and other complementary $[8,11,12]$.

Regarding treatment, the most appropriate option is the radical surgical excision of the lesions and their anatomopathological study. Some cases may even require abdominoperineal amputation. Other treatments that have been used in some cases are chemo and radiotherapy, as well as topical treatments although the available bibliographic evidence is not conclusive regarding the systematic use of them, tending in general terms to be ineffective [12-14]. 


\section{Conclusions}

Definitive diagnosis: Tumor of Buschke-Lõwenstein or Giant Cumulated Condyloma.

Surgical treatment: Excision of inguinal lesions and electro fulguration of anal lesions.

Evolution: Satisfactory. There have been no recurrences in the assessment performed at 3 months.

\section{References}

1. Gearhart PA, Randall TC, Buckley RM, Higgins RV (2007) Human papillomavirus (HPV). Medscape.

2. Chu QD, Vezeridis MP, Libbey NP, Wanebo HJ (1994) Giant condyloma acuminatum (Buschke-Lowenstein tumor) of the anorectal and perianal regions. Analysis of 42 cases. Dis Colon Rectum 37: 950957.

3. Tas S, Arik MK, Ozkul F, Cikman O, Akgun Y (2012) Perianal Giant Condyloma Acuminatum-Buschke-Löwenstein Tumor: A Case Report. Case Rep Surg 2012: 507374.

4. Rhea WG Jr, Bourgeois BM, Sewell DR (1998) Condyloma acuminata: a fatal disease? Am Surg 64: 1082-1087.

5. Hermosa ARL, Hurtado-Caballero E, Zorrilla-Ortúzar J, ValleHernández ED, Muñoz-Jimenez F (2011) Tumor de BuschkeLowenstein asociado a condilomatosis nasofaríngea. Revista de Gastroenterología de México 76: 275-278.

6. Kreuter A, Wieland U (2011) Giant Condyloma Acuminatum of Buschke and Löwenstein. N Engl J Med 365: 1624
7. González DR, Piñero CJP, Nápoles CMS (2014) Infection by the human papillomavirus and associated factors in middle-aged women. Rev Cubana Obstet Ginecol 40: 218-232.

8. Vega-Malagón G, Ávila-Morales J, García-Solís P, Camacho-Calderón $\mathrm{N}$, Becerril-Santos A, et al. (2014) Infection with the human papiloma virus. Molecular biology. European Scientific J 10: 352-363.

9. Pennacchiotti G, Sáez R, Martínez MJ, Cárcamo M, Montes R (2016) Human papilloma virus prevalence in patients diagnosed with squamous carcinoma oral cavity. Rev Chil Cir 68: 137-142.

10. Medina-Fernández IA, Gallegos-Torres RM, Cervera-Baas ME, Cob-Tejeda RA, Jiménez-Laces J, et al. (2017) Knowledge of the human papilloma virus and its vaccine in women in a rural area of Querétaro, México. Revista Enfermería Costa Rica 32: 26-39.

11. Barrios-García L, Lecompte-Osorio PA, Leones-Castillo RA, LópezCustode FR (2016) Factores de riesgo presentes en pacientes con lesiones intraepiteliales escamosas del cérvix en la Clínica Maternidad Rafael Calvo en la ciudad de Cartagena (Colombia): estudio descriptivo. Arch Med (Manizales) 16: 109-117.

12. Morales LA, Rincón DF, Rincón-Orozco B (2016) Advances in the development of new prophylactic and therapeutic vaccines against Human Papillomavirus. Rev Univ Ind Santander Salud 48: 385-391.

13. Bustamante BJP (2016) La vacuna contra el Virus del Papiloma Humano: estado de la cuestión, principio de proporcionalidad y consentimiento informado. Acta bioeth 22: 251-261.

14. Martínez GG, Troconis JN (2015) Tratamiento de las verrugas genitales: una actualización. Rev Chil Obstet Ginecol 80: 76-83. 